\title{
Research on Chinese Men's Shirt Industry Based on Market Structure-Conduct-Performance Framework
}

\author{
Jian WU, An LU* \\ Beijing Institute of Fashion Technology, Beijing, China \\ ${ }^{*}$ Corresponding author
}

Keywords: Men's Shirt Industry; Market Structure-Conduct-Performance; Concentration.

\begin{abstract}
This paper uses the market Structure-Conduct-Performance framework to analyze male shirt brands in the Chinese market. In the research process of domestic male shirt market behavior and performance, it is verified that the domestic male shirt market structure is a competitive structure. China's men's shirt industry has gradually matured, and a single big situation has passed.
\end{abstract}

\section{Introduction}

The market structure-conduct-performance framework is an important tool for analyzing industrial organizations. The theory was proposed by American economist Bain and is a commonly used theory of industrial organization. The market structure is the environment in which the economy operates, the market behavior is the way of economic operation, and the market performance is the operational effect of the economy. Through the analysis of the domestic men's shirt market through three factors, it can make a reasonable assessment of the domestic men's shirt market and provide a reference direction for the development of the domestic men's shirt industry.

\section{Overview of the Development of the Male Shirt Industry in the Domestic Market}

The current men's shirt market is very dynamic. According to the statistics of the China National Business Center, from 2015 to 2016, the sales growth of men's shirts among the top 100 large-scale retail enterprises nationwide exceeded $8 \%$. This increase is the highest among all types of apparel sales. In 2017, Youngor men's shirts led the other brands with a market share of $6.53 \%$, the second and third were Goldlion (2.84\%) and Jiu Joeone (2.19\%). Not only that, Youngor is the first in the market share of men's shirts for 17 years, and Youngor men's shirts are the country's first inspection-free export products. According to the data sample given by the China Business Federation in 2016, Youngor has the largest market share of men's shirts in both first- and third-tier cities, as shown in Table 1. By 2011, the total market value of Youngor Group reached 60 billion yuan, and the financial strength was very strong. However, compared with the overall market share of $13.2 \%$ in 1999, the market share of Youngor men's shirts is shrinking, and the market share of Youngor men's shirts is constantly being eaten by domestic and foreign brands.

Table 1. Ranking of market share of men's shirts of major brands in major retail enterprises in 2016

\begin{tabular}{c|c|c|c}
\hline Ranking & First-tier city & Second-tier cities & third-tier city \\
\hline 1 & Youngor & Youngor & Youngor \\
\hline 2 & Shachi & Conch & Goldlion \\
\hline 3 & Goldlion & Pierre Cardin & Joeone \\
\hline 4 & Conch & Kaikai & Playboy \\
\hline 5 & Lacoste & Laorentou & Heng Yuanxiang \\
\hline 6 & Pierre Cardin & Heng Yuanxiang & Romon \\
\hline 7 & Kaikai & JackJones & Saint Desi \\
\hline 8 & Sabatini & GY & Binbin \\
\hline 9 & CERRUTI 1881 & Goldlion & JackJones \\
\hline 10 & Jeep & Joeone &
\end{tabular}


From another perspective, China's accession to the WTO has a certain impact on domestic men's shirt brands. In 1999, the top 10 men's shirts were domestic brands, and after more than a decade, the pattern of men's shirts in the domestic market has changed a lot. Many domestic shirt brands have left the TOP10 list and replaced them with overseas brands such as Shachi, Pierre Cardin and Playboy.

Table 2. Sales Status of Clothing Brand in Key National Large-scale Shopping Malls in 1999

\begin{tabular}{c|c|c|c}
\hline brand & Market share (\%) & brand & Market share (\%) \\
\hline Youngor & 13.2 & Qinman & 4.6 \\
\hline Kaikai & 8.2 & Peacebird & 2.6 \\
\hline Hubao & 8.0 & Busen & 2.3 \\
\hline Rouse & 5.7 & Goldlion & 2.3 \\
\hline Conch & 5.4 & Other & 42.4 \\
\hline Fushen & 5.1 & & \\
\hline
\end{tabular}

Source: China National Business Center: "Market Sales Status of National Major Large-scale Shopping Malls in 1999”, Textile Standards and Quality, No. 3, 2000, p. 8.

\section{Analysis of the Domestic Men's Shirt Market Structure}

The main factors determining the market structure are: market concentration, product differentiation, and market advancement and retreat. The above factors that determine the structure of the market are mutually influential. When a certain factor changes, it will lead to changes in other factors in the market structure, thus changing the market structure characteristics of the industry. According to the data of these years, it can be calculated that the current domestic male shirt market is a competitive market structure, and the degree of differentiation of each male shirt product is not obvious. The barriers for companies to enter or exit the market are not high, and new faces of men's shirt brands are constantly appearing in the market.

\section{Market Concentration}

Market concentration refers to the market share occupied by a few of the largest companies (usually the top four, the top five and the top eight) in a particular market, and refers to the concentration of production and operation in a particular industry. The system concentration can be directly calculated from the market share of the first few companies in the industry. The calculation formula (1) is:

$$
\mathrm{CRn}=\sum_{i=1}^{n} S_{i}
$$

Where: $\mathrm{CRn}$ is the industry concentration of the top $\mathrm{n}$ companies in the industry;

$\mathrm{n}$ is the total number of enterprises in the industry; it is the market share of the $\mathrm{i}$-th enterprise in the industry.

According to the sales situation of the national key large-scale shopping mall clothing brand in 1999, the domestic male shirt market value can be calculated as $35.1 \%$, with a value of $52.8 \%$. According to Bain's market structure classification, it can be seen that the domestic male shirt market in 1999 was an oligopolistic IV market structure.

Table 3. Concentration of China's Men's Shirt Industry in 2002

\begin{tabular}{ccccc}
\hline \multicolumn{4}{c}{ Comprehensive share of the top four brands (\%) } & $\mathrm{C}_{4}$ value \\
\hline Youngor & Rouse & Peacebird & Kaikai & - \\
\hline 9.5 & 6.11 & 4.70 & 4.21 & 24.52 \\
\hline
\end{tabular}

Data source: According to the 2002 China Commodity Information Center, the national large-scale retail enterprises measured the sales of goods in 2002.

By 2002, the value of the Chinese men's shirt market had dropped to 24.52\%. As shown in Table 3 , the market structure at this time was a competitive market type. By 2014, the market value of men's shirts has further decreased. Despite the lack of accurate occupancy of Goldlion and Pierre 
Cardin, the overall trend of value is declining. After 2014, the value reduction rate slowed down. By the end of 2016, the industrial concentration of men's shirts in China was only $13.44 \%$. At this time, the domestic men's shirt industry is very competitive.

Table 4. Concentration of China's Men's Shirt Industry in 2014

\begin{tabular}{ccccc}
\hline \multicolumn{4}{c}{ Comprehensive share of the top four brands ( \%) } & $\mathrm{C}_{4}$ value \\
\hline Youngor & Rouse & Goldlion & Pierre Cardin & - \\
\hline 6.86 & 2.68 & about 2 & about 2 & - \\
\hline Source: Forward-looking industry research apparel industry & database & &
\end{tabular}

Table 5. Concentration of China's Men's Shirt Industry in 2016

\begin{tabular}{ccccc}
\hline \multicolumn{3}{c}{ Comprehensive share of the top four brands (\%) } & \multicolumn{2}{c}{$\mathrm{C}_{4}$ value } \\
\hline Youngor & Goldlion & Joeone & Conch & - \\
\hline 6.53 & 2.84 & 2.19 & 1.88 & 13.44 \\
\hline
\end{tabular}

Source of data: Calculated according to data from the China Business Federation.

\section{Entering the Exit Barrier}

Due to the high degree of free competition in the domestic men's shirt market, the entry barrier for the male shirt market is currently lower than in 1999. Especially in the clothing industry cluster area, because of its good location advantage, the industry entry barrier is even lower. Due to the high degree of competition, it can be seen that the ranking of male shirt brand share has changed greatly between 2014 and 2016. Pierre Cardin fell out of the top 4, and Goldlion climbed from the third to the fifth, Joeone and Conch also joined the top four. Judging from the distribution of market share, there are a large number of small enterprise products in the domestic men's shirt market. In particular, many large brands now use the OEM model. Many foundries also sell their products to the outside world in order to increase the profits of the company. Some even open stores on the e-commerce platform. With the production experience of big brand men's shirts, the quality of the men's shirts they sell and sell are not bad.

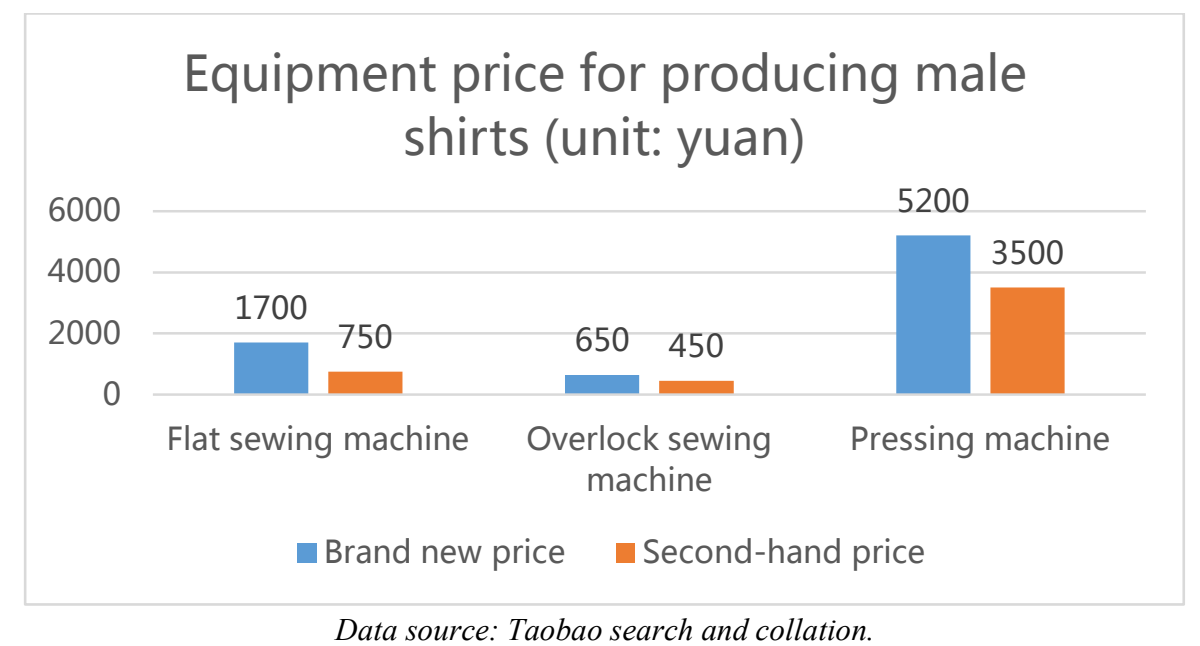

Figure 1. Price of Major New and Old Equipment Required for the Production of Men's Shirts (Taobao)

As shown in Figure 1, since the equipment needed to produce a male shirt is a mass-produced device, each company can be well compatible, so the sunk cost is relatively low when the company exits the market. From the point of view of dismissal expenses, since the production of men's shirts is a capital-intensive industry, automation equipment is everywhere in the factory, so the dismissal costs are relatively low. Finally, the government has not deliberately embarrassed those companies that are ready to withdraw from the market. 
Overall, due to the middle of the industry, a large number of clothing companies want the men's shirt industry to have their own market share. This further proves that the current market for male shirts is highly competitive.

\section{Market Conduct Analysis}

The domestic male shirt market behavior refers to the general market behavior of the industry from the middle level of the male shirt industry in the domestic market, rather than just examining the market behavior of a single enterprise. In the domestic men's shirt market, companies mainly adopt price behavior and organizational adjustment behavior as the source of marketing revenue growth.

Nowadays, the gap between many men's shirt brands in the domestic market is very small. Many brands want to find a difference in the men's shirt industry and need to find another way. And because the current market concentration is too low, the competition is too fierce, and the price has become the dominant factor affecting market share.

\section{Price Behavior}

It is not the analysis of a certain enterprise in the industry, but the price behavior of several male shirt companies can be roughly obtained: price discount, promotion pricing and differential pricing. Among them, price discount and promotional pricing are the two main price behaviors in the domestic men's shirt market.

From the sales data of the domestic e-commerce platform, the unit price of men's shirts averaged 87.06 yuan / piece, the unit price decreased by $7.76 \%$ compared with the previous year, as shown in Table 6:

Table 6. Sales of Male Shirts in Domestic E-commerce Platform in 2016

\begin{tabular}{|c|c|c|c|c|c|}
\hline $\begin{array}{l}\text { Sales }(100 \\
\text { million } \\
\text { yuan) }\end{array}$ & $\begin{array}{l}\text { Sales } \\
\text { year-on-year } \\
(\%)\end{array}$ & $\begin{array}{l}\text { Sales volume } \\
(100 \text { million } \\
\text { pieces })\end{array}$ & $\begin{array}{l}\text { Sales } \\
\text { volume } \\
\text { year-on-year } \\
(\%)\end{array}$ & $\begin{array}{l}\text { Unit price } \\
\text { (yuan/piece) }\end{array}$ & $\begin{array}{l}\text { Unit price } \\
\text { year-on-year } \\
(\%)\end{array}$ \\
\hline 82.46 & -16.54 & 0.95 & -9.52 & 87.06 & -7.76 \\
\hline
\end{tabular}

Source: China Men's Wear Industry Development Report 2017, China Textile Press.

While the sales of men's shirts on the e-commerce platform have dropped sharply, the online sales prices of various brands have also been correspondingly reduced to reduce the negative impact of market fluctuations. However, from the perspective of the domestic male shirt market, the scale has not shrunk, which may be related to the offline market, and there is no excessive research here.

\section{Organizational Adjustment Behavior}

Corporate mergers and acquisitions are a common corporate organizational adjustment behavior. Corporate mergers and acquisitions have a great impact on the market structure. The general clothing enterprises not only manage the male shirts, so the analysis of the mergers and acquisitions needs to be combined with the strategic perspective of the apparel enterprises. The products under the brand are related. From the perspective of the entire men's lining industry, many companies have had mergers and acquisitions. In the case of Youngor, in 2007, Kellwood and its wholly-owned subsidiary Kellwood Asia Limited were acquired. Kellwood's core business is clothing, which is well known internationally. Similar mergers and acquisitions also existed with other companies, such as Joeone in 2010 acquired the Italian brand VIGANO China's general agent.

Corporate mergers and acquisitions are a strategic move by the company in its operations. In the men's shirt industry, due to fierce competition, every company wants to find the next growth point. "Price war" is not a long-term solution, so these companies need to find the difference between men's shirts. The acquisition of outstanding companies will undoubtedly bring the most direct help to the company, such as the design style of men's shirts, fabric materials, brand style and so on. 


\section{Performance Analysis of Domestic Men's Shirt Market}

The domestic male shirt market performance refers to the resource allocation and benefit distribution status formed by the domestic male shirt industry through the market behavior of the male shirt enterprise under the certain male shirt market structure. Since the relevant data in resource allocation efficiency is extremely difficult to obtain, it is only analyzed from the profit level and technological progress.

\section{Profit Level}

From the perspective of microeconomics, in the complete competitive market structure, the sign of optimal allocation of resource allocation is that all enterprises in the industry can only obtain normal profits, and the profit rate among enterprises tends to be consistent. In the domestic men's shirt market, because it is difficult to obtain a separate profit margin for a specific brand of men's shirts, the clothing profit levels of several brands in the men's shirt market are used here as a reference.

Table 7. Profits of Several Male Shirt Brand Companies in 2010

\begin{tabular}{|c|c|c|c|c|c|c|}
\hline \multirow{2}{*}{$\begin{array}{l}\text { company } \\
\text { name }\end{array}$} & \multicolumn{2}{|c|}{ Main business income } & \multicolumn{2}{|c|}{ Total profit } & \multicolumn{2}{|c|}{ Net profit } \\
\hline & $\begin{array}{l}\text { Amount } \\
\text { (ten } \\
\text { thousand } \\
\text { yuan) }\end{array}$ & $\begin{array}{l}\text { Year-on-year } \\
\text { growth (\%) }\end{array}$ & $\begin{array}{l}\text { Amount } \\
\text { (ten } \\
\text { thousand } \\
\text { yuan) }\end{array}$ & $\begin{array}{l}\text { Year-on-year } \\
\text { increase }(\%)\end{array}$ & $\begin{array}{l}\text { Amount } \\
\text { (ten } \\
\text { thousand } \\
\text { yuan) }\end{array}$ & $\begin{array}{l}\text { Year-on-year } \\
\text { increase }(\%)\end{array}$ \\
\hline Youngor & 1451359.05 & 18.20 & 366072.33 & -10.66 & 267217.19 & -18.13 \\
\hline Kaikai & 86689.78 & 0.14 & 3258.61 & -26.39 & 2670.38 & -32.40 \\
\hline Septwolves & 219775.66 & 10.59 & 33925.02 & 30.79 & 28315.69 & 38.87 \\
\hline
\end{tabular}

As can be seen from Table 7 above, Youngor's net profit, which ranks first in the domestic men's shirt market, has decreased by $18.13 \%$ year-on-year. Not only that, but the net profit opened has also been decreasing. The Septwolves has a slightly higher margin of profit due to its lower share in the men's shirt market. But from a long-term perspective, if there is no major change in the market, the profit margin of the Septwolves will tend to stabilize.

\section{Technological Progress}

In recent years, the technological progress of the garment industry has been very rapid, as has been the case in the field of men's shirts. As a leading company, Youngor has obtained more than 80 patents. From 1995 to now, there are 8 invention patents in the field of men's shirts. Other companies have also made innovations and technological breakthroughs in fabrics and cutting. In general, these technologies and breakthroughs are mainly for the sake of their own brand of men's shirts can be different from other brands, to create their own selling points. From the current point of view, domestic male shirt brands still have some gaps in design styles and foreign brands.

\section{Conclusion}

This paper uses the market structure-conduct-performance framework to study the domestic men's shirt market and draws the following conclusions: At present, the domestic male shirt market structure is a competitive market structure, and the competition is fierce; the average single piece of men's shirts in the domestic market Prices are gradually decreasing; large companies have mergers and acquisitions; the profit rate of the men's shirt market is gradually averaging the average profit rate; each manufacturer is positive in terms of technological innovation.

\section{References}

[1] Lu An, Hao Shuli. Clothing Industry Organization [M]. Beijing: People's Publishing House, 2013, 26-135. 
[2] China Changshu Men's Wear Index Preparation and Release Center. China Men's Wear Industry Development Report 2017 [J]. Beijing: China Textile Press, 2017, 6-14.

[3] China Garment Association. 2016-2017 China Garment Industry Development Report [J]. Beijing: China Textile Press, 2017.

[4] China National Textile and Apparel Council. 2017/2018 China Textile Industry Development Report [J]. Beijing: China Textile Press, 2018.

[5] Ma Xiaohong, Ma Tao. Introduction to China's Textile Economy [M]. Beijing: Metallurgical Industry Press, 2013.

[6] Gao Yuemei. Research on the development of China's garment industry since the reform and opening up [M]. Beijing: China Textile Press, 2016. 